\title{
CHANGE OF TGF- $\beta 1$ CONCENTRATION IN BLOOD SERUM OF PATIENTS DURING SYSTEMIC TREATMENT OF SEVERE PSORIASIS
}

\author{
Iveta Ivdra, llona Hartmane, and Ingmars Mikažāns* \\ Skin and STD clinical centre, Briāna iela 2, Rīga LV-1001, LATVIA \\ *Pauls Stradinš Clinical University Hospital, Pilsoṇu iela 13, Rīga LV-1002, LATVIA
}

Communicated by Alfrēds Miltinš

\begin{abstract}
TGF- $\beta 1$ is a growth factor with multiple actions, responsible for many pathological and physiological processes. Radiation of the skin with a narrowband $311 \mathrm{~nm}$ UVB light source is the most often used method of therapy in psoriasis treatment. The aim of the study was to compare different therapy methods on the change of TGF- $\beta 1$ serum concentration during two weeks of treatment. The TGF- $\beta 1$ concentration in blood serum of patients with psoriasis was statistically significantly lower than in the control group. For psoriasis treatment, narrow band $311 \mathrm{~nm}$ UVB phototherapy was applied to 37 patients and systemic pharmacological treatment with metothrexate, to a group of 18 patients. After two weeks, there was a significant reduction of Psoriasis Area and Severity Index (PASI) and increase of TGF- $\beta 1$ serum concentration. Narrowband UVB caused a lower $P A S I$, and higher TGF- $\beta 1$ serum concentration than did pharmacological systemically treatment. Growth factor TGF- $\beta 1$ had an effect on both of these processes. Lack of TGF- $\beta 1$ in psoriatic skin is responsible for TH1-induced immune reactions and intensive proliferation of keratinocytes, which are typical of psoriasis. UVB radiation results in a higher TGF- $\beta 1$ tissue concentration. Elevation of TGF- $\beta 1$ concentration in blood serum and skin after UVB may present a possible mechanism for the positive effect of UVB in psoriasis treatment.
\end{abstract}

Key words: psoriasis, TGF- $\beta 1$, narrow band $311 \mathrm{~nm}$ UVB phototherapy.

\section{INTRODUCTION}

TGF- $\beta 1$ (transforming growth factor- $\beta 1$ ) is a universal growth factor with a wide action spectrum. It is found in all living cells. TGF- $\beta 1$ is one of the leading cytokines during embryonic development, and it regulates organism formation. Especially large amounts of TGF- $\beta 1$ accumulate in sites where intensive morphogenesis and differentiation of tissue is occurring. TGF- $\beta 1$ ensures homeostasis in cells and also tissue regeneration in adults (Massague, 1990).

TGF- $\beta 1$ influences practically all cellular actions - adhesion, movement, differentiation, proliferation and apoptosis. Changes in the action of TGF- $\beta 1$ growth factor, or receptors and signal molecules subordinated to it, are associated with many diseases, generation of benignant and malignant tumours and aging (Go et al., 1999; Massague, 2000).

TGF- $\beta 1$ is one of the most powerful inhibitors of cell proliferation and growth, (Sellheyer et al., 1993). However, its potential for inhibition regarding various types of cells differs, and frequently is even in the diametrically opposite direction (De Jong et al., 1993). TGF- $\beta 1$ induced inhibition of keratinocytes is characterized by reversible retention of proliferation, extending or stopping of cell division cycle in the G1 phase (Van Ruissen et al., 1994; Ten Dijke et al., 2002). Proliferation of keratinocytes is delayed through the intervention of multiple TGF- $\beta 1$ conditional mechanisms, the large part of which is not yet understood. It is well known that this cytokine influences expression of several molecules associated with the cell cycle, including also CDK inhibitors (p15, p-21, p-27, CDK phosphatase, protooncogens) and Cmyc and Cjun (Saltis, 1996; Ravitz; 1997; Pardali K. et al., 2000; Mauviel, 2009).

In normal skin, TGF- $\beta 1$ inhibits regulation of keratinocytes growth, protecting the epidermis from extreme thickening. Inhibition of keratinocyte proliferation is the main precondition for the initiation of differentiation (Dahler et al., 2001).

TGF- $\beta 1$ can be eliminated from the organism's extracellular environment, including blood, within three minutes. In the extracellular environment cytokine TGF- $\beta 1$ can become in contact with specific extracellular matrix and plasma proteins. There exists an opinion that this mechanism forestalls 
elimination of TGF- $\beta 1$ from the body and ensures accumulation of a reserve (Khalil, 1999).

We evaluated change of TGF- $\beta 1$ concentration in serum during psoriasis treatment and compared the effect of two different systemic therapy methods on disease symptoms and concentration of TGF- $\beta 1$ in serum.

Skin irradiation with narrow band $311 \mathrm{~nm}$ UVB wavelength is one of the most frequently used treatment methods in cases of severe psoriasis. Narrow band UVB phototherapy is more effective and safe than wide spectrum 280-320 nm UVB. It has been shown that UV light waves with pike emission $311 \mathrm{~nm}$ have a greater anti-psoriatic effect, but have minimal impact on creation of skin erythema. UV radiation of the skin is absorbed in specific molecules - endogenous hromophors - resulting in a cascade of photochemical reactions. This action alters biomolecular processes in the skin and causes the treatment effect (Honingsmann et al., 1993; Weichenth et al., 2005).

Methotrexate is used as an alternative in severe psoriasis treatment. It slows down the conversion of folic acid into tetrahydrofolate, its active form, which is followed by the inhibition of DNA synthesis, caused by the inhibition of thymidine synthesis and methylation of purine. As a result, the $\mathrm{S}$ phase of the mitotic cycle is stopped and cell apoptosis is initiated. The main target cells for the action of methotrexate in case psoriasis cases are $\mathrm{T}$ lymphocytes, and 95\% of the T-lymphocyte population is affected. The larger part of keratinocytes in psoriatic skin are in S phase, which can explain the high methotrexate-induced inhibition of psoraic tissue, compared with normal epidermis. Simultaneous use of narrow band 311 UVB phototherapy and metotrexate during the treatment of psoriasis is rare, as this synergy can increase risk of carcer. In addition, methotrexate has a photosensitive effect (Cueller et al., 1997; Jeffes et al., 1995).

The aim of the research was to evaluate the influence of different impact treatment methods on change of TGF- $\beta 1$ concentration in blood serum of patients with severe psoriasis.

\section{MATERIALS AND METHODS}

A group of 55 patients with severe extended vulgar and guttate forms of psoriasis were examined and treated. We determined the concentration of TGF- $\beta 1$ in blood serum of all patients before treatment and after two weeks of therapy. To obtain more precise results, we did not include individuals in which other concomitant diseases were diagnosed. The severity of psoriasis in patients was characterised by BSA (BSA - Body Surface Area) more than 10\%. BSA denotes percentage area of rashes against total surface of the skin. A level of more than 10 percent of skin area covered by psoriasis skin rashes corresponds to a severe form of this disease. Despite that, many authors have offered different values for BSA to define the degree of severity of psoriasis, BSA $>10 \%$ is set as essential borderline, when systemic therapy for psoriasis must be included in addition to local treatment. We determined also the concentration of TGF- $\beta 1$ in blood serum of 20 clinically healthy individuals as a control group.

Patients were selected according to the following criteria: Inclusion:

- Patients with psoriasis, age 18-65 years

- $\mathrm{BSA}>10 \%$

- Psoriasis in acute condition at the time of selection Exclusion:

- Pregnancy

- Presence of chronic concomitant diseases

- Oncologic illness at the time of selection or in anamnesis

- Acute respiratory illness during the last seven days

- Active systemic treatment received during the last month regarding psoriasis or psoriatic arthritis

- Usage of alcohol during the last seven days

- Sunbathing or a visit to the solarium during the last seven days

The mean TGF- $\beta 1$ serum concentration in the sampled population of psoriasis patients were compared to that in the control group. After two weeks of treatment, TGF- $\beta 1$ serum concentration for the patients again determined. Psoriasis Area and Severity Index (PASI) also was estimated for all patients, before and after the two-week treatment course for measurement the effectiveness of therapy.

PASI was calculated according to the following formula:

$\mathrm{PASI}=0.1 \times(\mathrm{Eh}+\mathrm{Ih}+\mathrm{Dh}) \times \mathrm{Ah}+0.2 \times(\mathrm{Eu}+\mathrm{Iu}+\mathrm{Du}) \times \mathrm{Au}+0.3 \times$ $(\mathrm{Et}+\mathrm{It}+\mathrm{Dt}) \times \mathrm{At}+0.4 \times(\mathrm{El}+\mathrm{Il}+\mathrm{Dl}) \times \mathrm{Al}$

The main signs of rushes $(\mathrm{E}=$ erythema, $\mathrm{I}=$ induration, and $\mathrm{D}=$ desquamation) were rated on a 0 to 4 point, where $0=$ without symptoms, 1 = slightly pronounced, 2 = moderately pronounced, $3=$ severely pronounced, and $4=$ very severely pronounced. The weightings $0.1,0.2 ; 0.3$; and 0.4 included in the formula are based on the relative skin area in four main anatomical regions - head and neck (h), upper extremities (u), trunk (t), lower extremities (1). A (area) denotes percentage volume of skin rushes on the following scale: $1>10 \%$; 2 (10-29\%); 3 (30-49\%); 4 (50-69\%), 5 (70-89\%), 6 (90-100\%) (Ahmad et al., 2008).

Blood serum was centrifuged $(1000 \mathrm{G})$ and frozen at $-20{ }^{\circ} \mathrm{C}$ until analysis. TGF- $\beta 1$ concentration was measured by an immune sorbent method (ELISA - enzyme - linked immune sorbent assay). Concentrations were calculated by comparison of TGF- $\beta 1$ light absorption with a reference 
curve obtained by estimated light absorption by standard TGF- $\beta 1$ samples of known concentration.

Statistical analysis of the data was performed using SPSS version 17.0 software (The Statistical Package for the Social sciences, SPSS, Chicago). The Mann-Whitney nonparametric-test $U$ test for two independent samples and Wilcokson non-parametric test for two related samples were used. Alongside the $P$ value, the $U$ criteria for the MannWhitney nonparametric-test $\mathrm{U}$ test and $\mathrm{Z}$ criteria for the Wilcokson non-parametric test were determined.

\section{RESULTS}

The average PASI score of the examined patients population with severe psoriasis (BSA $>10 \%$ ) was $27.0 \pm 1.4$, and the average TGF- $\beta 1$ serum concentration was $19668.4 \pm$ $1046.4 \mathrm{pg} / \mathrm{ml}$. Total TGF- $\beta 1$ serum concentration in the psoriasis patient group was significantly lower then in the control group $(\mathrm{U}=238 ; P<0.001)$ (Mann-Whitney non-parametric test for two independent samples).

Thirty-seven patients received $311 \mathrm{~nm}$ narrow band UVB phototherapy during treatment, following accordance with technical parameters of the medical UVB cabin and references for optimal and safe dosage of UV radiation, the initial flow in our study was $0.014-0.025 \mathrm{~J} / \mathrm{cm}^{2}$, depending on the photo type of the skin, and further elevated by $0.003-$ $0.018 \mathrm{~J} / \mathrm{cm} 2$ for each treatment session.

For the remaining 18 patients, systemic pharmacological therapy was chosen due to the following reasons: summer form of psoriasis, heightened skin sensitivity to UV radiation, suspicious or risk group of pigmentation on the skin, long-lasting eruption new rashes and indisposition from patient to undertake UVB. We also chose systemic pharmacological therapy for patients with severe or active psoriatic arthritis. The systemic pharmacological treatment included per orally administered methotrexate in an average dose 15 mg per week.

Before treatment, the average PASI score for patients who received phototherapy was $27.2 \pm 1.7$, and for the patients who received pharmacological systemic therapy $-26.4 \pm$ 2.4. The average initial TGF- $\beta 1$ concentration in patients who had received a $311 \mathrm{~nm}$ narrow band UVB phototherapy was $20325.8 \pm 1257.7 \mathrm{pg} / \mathrm{ml}$, and for patients who had received pharmacologic systemic treatment $-18317.2 \pm$ $892.7 \mathrm{pg} / \mathrm{ml}$. There were no significant differences between the groups in initial PASI score of $(\mathrm{U}=321 ; P>0.05)$ and TGF- $\beta 1$ concentration in blood serum $(\mathrm{U}=277 ; P>0.05)$ before the treatment (Mann-Whitney non-parametric test for two independent samples). During two weeks of treatment, a significant decrease in PASI was observed both for patients who received $311 \mathrm{~nm}$ narrow band UVB phototherapy $(\mathrm{Z}=-5.303 ; P<0.001)$ and for patients who received pharmacological systemic treatment $(\mathrm{Z}=-3.724 ; P<$ 0.001) (Wilcokson non-parametric test for two related samples). TGF- $\beta 1$ serum concentration increased significantly in patients who had received $311 \mathrm{~nm}$ narrow band UVB phototherapy $(\mathrm{Z}=-5.103 ; P<0.001)$ and in those who received pharmacologic systemic treatment with metotrexate ( $\mathrm{Z}=-3.637 ; P<0.001$ ) (Wilcokson non-parametric test for two related samples).

For the patients who received 311 narrow band UVB phototherapy, the average PASI decreased by $65.3 \pm 2.2 \%$, and for patients who received pharmacological systemic treatment by $56.5 \pm 4.2 \%$. After two weeks of treatment, the average PASI score for the patients who received $311 \mathrm{~nm}$ narrow band UVB phototherapy was $10.1 \pm 1.3$, and for the patients who were treated by the systemic therapy $-11.4 \pm$ 1.6. There was a significant decrease of PASI in the patients who received narrow band 311 UVB phototherapy in psoriasis treatment $(\mathrm{U}=217.5 ; P<0.05)$ (Mann-Whitney nonparametric test for two independent samples). Athough the patient group treated by $311 \mathrm{~nm}$ narrow band UVB phototherapy had a lower PASI score after the two weeks of treatment, compared to the systemic therapy, this difference was not significant $(\mathrm{U}=276 ; \mathrm{P}>0.05$ ) (Mann-Whitney nonparametric test for two independent samples). Comparing change in PASI, $311 \mathrm{~nm}$ narrow band UVB phototherapy was more effective in psoriasis treatment. The above results are in part due to the fact that the initial PASI score before treatment was larger in the $311 \mathrm{~nm}$ narrow band UVB phototherapy group than for the group treated by systemic applicable pharmacological means (methotrexate), but after two weeks of treatment course, the differences were opposite. After two weeks of treatment, the PASI scores had become rather similar between the groups.

After two weeks of treatment, the average TGF- $\beta 1$ serum concentration in patients who had received a $311 \mathrm{~nm}$ narrow band UVB phototherapy was $27778.4 \pm 1408.5 \mathrm{pg} / \mathrm{ml}$, and in patients who had been prescribed a pharmacologic systemic treatment $-22633.3 \pm 1998.2 \mathrm{pg} / \mathrm{ml}$. The average increase of TGF- $\beta 1$ serum concentration of patients who had received a narrow band $311 \mathrm{~nm}$ UVB phototherapy was $25.4 \pm 1.5 \%$, and in patients who had received pharmacologic systemic treatment $-20.4 \pm 2.7 \%$. The average absolute increase of TGF- $\beta 1$ blood serum concentration was $7452.6 \pm 555.0 \mathrm{pg} /$ and $6426.1 \pm 469.2 \mathrm{pg} / \mathrm{ml}$, respectively.

After two weeks of treatment by $311 \mathrm{~nm}$ narrow band UVB phototherapy, there was a significant increase of TGF- $\beta 1$ concentration in blood serum $(\mathrm{U}=165 ; P<0.05)$.

Also, the TGF- $\beta 1$ concentration value in blood serum was significantly higher $(\mathrm{U}=225,5 ; P<0.05)$ in patients who received UVB phototherapy, compared to those treated by the pharmacological systemic treatment (Mann-Whitney non-parametric test for two independent samples). The changes of TGF- $\beta 1$ serum concentration in patients treated with $311 \mathrm{~nm}$ narrow band UVB photherapy and in those perorally administered methotrexate are shown in Figure 1. After two weeks of treatment, the medians (shown as a line in the box on whisker plots) of both groups had increased, confirming the effect of the both types of treatment on TGF- $\beta 1$ serum concentration. 


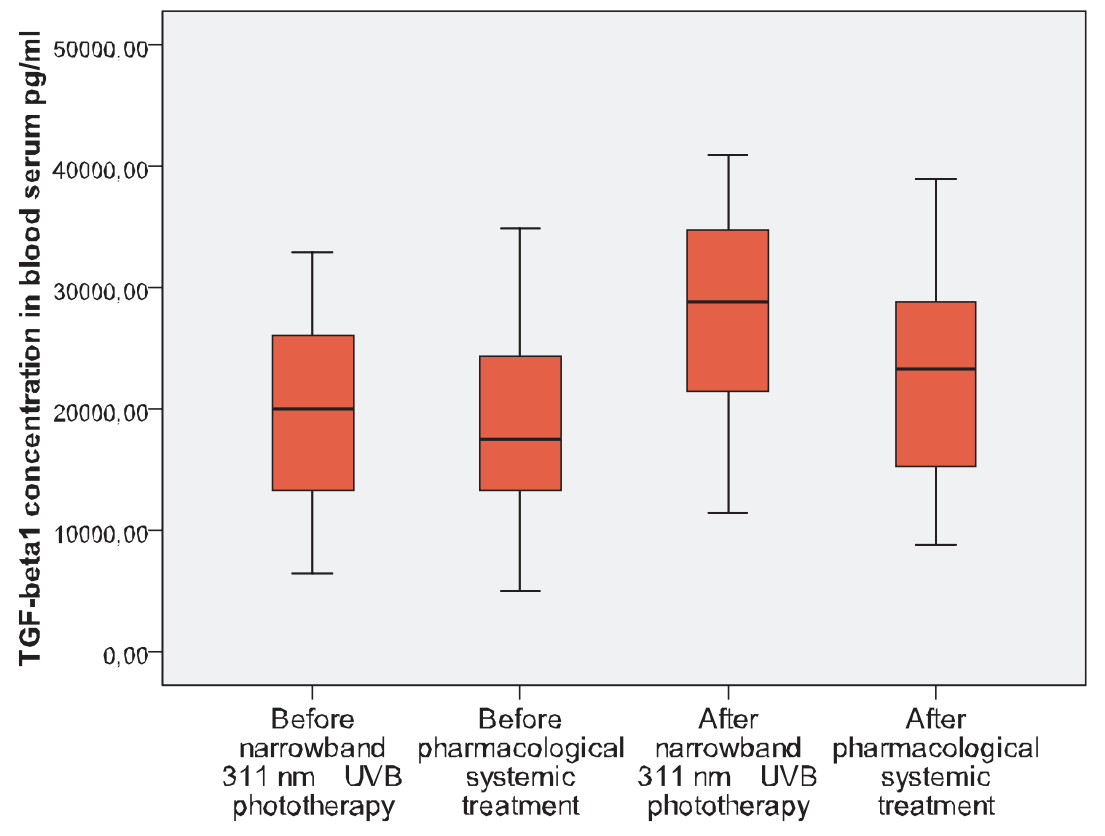

Fig. 1. TGF-beta 1 concentration in blood serum during treatment of psoriasis patients with BSA $>10 \%$.
At the end of the treatment course, the TGF- $\beta 1$ concentration for the patients who were treated by the phototherapy did not differ significantly from the control group $(\mathrm{U}=352$; $P>0.05)$. However, the serum concentration of TGF- $\beta 1$ after pharmacological systemic treatment remained significantly lower than in the control group $(\mathrm{U}=109 ; P<0.05)$.

\section{DISCUSSION}

TGF- $\beta 1$ has a major role in the pathogenesis of the psoriasis. This cytokine influences the activation of skin immune system. A change in the production of TGF- $\beta 1$ and its receptors cause serious deviations in the regulation of proliferation and differentiation of keratinocytes (Wang et al., 1997). There are still very contradictory and often even diametrically opposite observations on pathogenetic mechanisms of TGF- $\beta 1$ action mentioned in the scientific literature. TGF- $\beta 1$ is related with aging. As it is one of the initiators of fibroblast migration proliferation and differentiation, TGF- $\beta 1$ causes extracellular matrix synthesis, which contains collagen and fibronectin. If extracellular matrix accumulates outside the cell space protractedly, it serves not only as a replacement of damaged tissues, but also causes slow destruction of healthy tissue structure, which results in the development of fibrosis and sclerosis. Fibrosis and sclerosis are the basis for many aging diseases (Ohsugi et al., $2000)$. The amount of TGF- $\beta 1$ in tissues increases when aging is rapid (Widom, 2000). Therefore, the upper age limit (up to 65 years) of the patients included in the research was chosen in accordance with the second maximum of morbidity of psoriasis.

TGF- $\beta 1$ concentration in blood serum reflects sums of its free active as well as passive bounded forms. TGF- $\beta 1$, which is synthesized by blood cells and other tissues, is joined with LTBP complex and is accumulated in blood platelet cells in its passive nonactive form. Thereby, blood plasma is the main reservoir for TGF- $\beta 1$. By necessity, TGF- $\beta 1$ can be activated and delivered to target tissues outside the blood-vessels (Dennler et al., 2002). The total balance amount of accumulated TGF- $\beta 1$ is defined by its synthesis and consumption. The lack of TGF- $\beta 1$ in skin is related with hyper proliferative and an incompletely differentiated phenotype of keratinocytes. Such a phenotype of keratinocytes is definable in regions of psoriatic papules (Wang et al., 1997). One of the reasons for decreased TGF-b1 is its insufficient production in skin fibroblasts (Oyama et al., 2000). This condition meets with failure to inhibit proliferation of keratinocytes. In normal skin, TGF- $\beta 1$ produced by skins fibroblasts affect skins keratinocytes and delay their cell cycle division in a paracrine way.

In our study, we observed a reduced amount of TGF- $\beta 1$, which was associated with development of psoriatic features, shown by different levels in blood serum of patients and clinically healthy individuals. We determined TGF- $\beta 1$ serum concentration in psoriatic patients with severe extended (BSA 10\%) vulgar forms of psoriasis. The TGF- $\beta 1$ serum concentration in psoriatic patients was significantly lower $(P<0.001)$ than in the control group.

Many studies have shown that TGF- $\beta 1$ does not differ in anti proliferative effect in psoriatic and normal keratinocyte cultures. After in vitro addition to tissues cultures of TGF- $\beta 1$ growing factor in a concentration of $1 \mathrm{ng} / \mathrm{ml} 40$ $\mathrm{pM}$, psoriatic and normal keratinocytes were equally sensitive to the inhibiting influence of this growing factor, indicating that TGF- $\beta 1$ receptors expression is similar in psoriatic and normal epidermis (Elder et al., 1990). Therefore, there is a need to emphasise changes in the amount of TGF- $\beta 1$ in the development of psoriatic immune pathogenetic mechanisms.

There also is an urgent question whether the decreased TGF- $\beta 1$ serum concentration in the psoriatic patients is the 
reason for the decreased synthesis of the growing factor, or if it is the result of undue consumption. If the production of TGF- $\beta 1$ is decreased, it is necessary to study those areas where the decreased TGF- $\beta 1$ production is located - is it just in the skin or also in the blood.

Decreased TGF- $\beta 1$ serum concentration has also been observed for the larger part of autoimmune diseases, such as, Cavasaki disease, lupus erithematosus, multiple sclerosis, Schoegren syndrome and rheumatoid poliarthritis (Matsubara et al., 1997; Mahon et al., 2003; Caserta et al., 2004; Lu et al., 2004; Mieliauskaite et al., 2009; Hammad et al., 2006). Autoimmune origin of psoriasis is not proved yet. Similar to autoimmune diseases, psoriasis can be characterized by higher amount of NK cells, TH1, TH17 lymphocytes in the blood and disordered action of Treg cells. Treg cells, which compose 5-10\% of all population of T lymphocytes, are powerful suppressors of T-cell activity. Exactly under the influence of TGF- $\beta 1$, the majority of CD4+ $\mathrm{CD} 25+\mathrm{T}$ naive cells differentiate to Treg cells ( $\mathrm{Su}$ et al., 2008). Additionally, in the presence of TGF- $\beta 1$, Treg cells gain more powerful suppressive qualities in relation to others T lymphocytes, and in turn significantly slow down development of acquired immune reaction regulated by the $\mathrm{T}$ lymphocytes (Fantini et al., 2004).

In experimental animals TGF- $\beta 1$ deficit in tissues and blood serum has been observed to can promote TH1 lymphocyteinduced autoimmune inflammation in cases of artificially promoted autoimmune allergic encephalomyelitis or collagen-induced arthritis (Rubtsov et al., 2007). Constitutionally increased production of TGF- $\beta 1$ in tissues or exogenous TGF- $\beta 1$ addition by gene therapy can ensure a beneficial treatment result or delay progress of disease in animals (Chen et al., 1998). While slowing down the inflammatory process, TGF- $\beta 1$ has many-sided suppressive influence on T and B lymphocytes, macrophage, neutrophil and NK cells (De Jong et al., 1993; Gray et al., 1994; Horwitz et al., 1999; Laouar et al., 2005; Shen et al., 2007).

As the result of TGF- $\beta 1$ action the number of inflammatory cytokines decreases, but increases the amount of regulatory cytokines, which are necessary for the recovery process in psoriasis (Arsura et al., 1996). TGF- $\beta 1$ slows down IL-12 production by antigen presenting cells and this way has a marked immunosuppressive effect. Insufficient production of IL-12 is not able to ensure TH1 lymphocyte differentiation in $\mathrm{Cd} 4+\mathrm{CD} 45 \mathrm{RO}+$ memory cells. Consequently, CD8+ cytotoxic reactions in the skin are suppressed (Letterio et al., 1998). One of the factors that can suppress the amount of produced TGF- $\beta 1$ and activity in the case of psoriasis, is over production of cytokines IFN- y THF-a, IL-1, IL -6 from TH1 cells (Ulloa et al., 1999; Bitzer et al., 2000).

UVB with radiation dose $300 \mathrm{~J} / \mathrm{cm} 2$ causes a significant increase of TGF- $\beta 1$ concentration in keratinocyte cultures after 4-8 hours, but in fibroblasts cultures, during 48 hours (Taihao et al., 2002; Han et al., 2005). In the frames of our study, we observed a clear and marked regression of psoriatic processes in patients who received $311 \mathrm{~nm}$ narrow band UVB as treatment. We observed also a significantly higher increase of TGF- $\beta 1$ serum concentration in the treated patients, compared with patients who were treated with systematically prescribed pharmacological drug metotrexate.

UVB radiation penetrates to the epidermis and the upper dermis of the skin, where it mainly influences keratinocytes and Langerhans cells, not passing deeper layers of the skin and the structures under them (Gamblicher et al., 2005). Therefore, the increase of TGF- $\beta 1$ serum concentration of the patients who received $311 \mathrm{~nm}$ narrow band UVB in treatment, may be related with the stimulation of TGF-b1 production in skin cells, and not with its its increase in blood.

In conclusion:

TGF- $\beta 1$ concentration in blood serum of patients with vulgar and guttate forms psoriasis was lower than in healthy individuals, and confirming the role of this growth factor in the pathogenesis of psoriasis.

Under the influence of UVB, the produced amount of TGF- $\beta 1$ by skin tissue increases, resulting in higher TGF- $\beta 1$ concentration in blood serum.

The stimulation of TGF- $\beta 1$ production by UVB is one of the pathogenic mechanisms, by which a therapeutically improvement can be reached in psoriasis treatment.

\section{REFERENCES}

Ahmad Fadzil, M.H., Ihtatho, D., Affandi, A.M., Hussein, S.H. (2008). Objective assessment of psoriasis erythema for PASI scoring. Conference proceedings: Annual International Conference of the IEEE Engineering in Medicine and Biology Society. IEEE Engineering in Medicine and Biology Society, pp. 4070-4073.

Arsura, M., Wu, M., Sonenshein, G.E. (1996). TGF beta 1 inhibits NF-kappa B/Rel activity inducing apoptosis of B cells: Transcriptional activation of I kappa B alpha. Immunity, 5, 31-40.

Bitzer, M., von Gersdorff, G., Liang, D., Dominguez-Rosales, A., Beg, A.A., Rojkind, M. Bottinger, E.P. (2000) A mechanism of suppression of

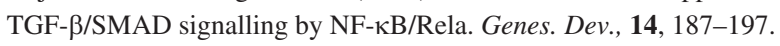

Caserta, T.M., Knisley, A.A., Tan, F.K., Arnett, F.C., Brown, T.L. (2004). Genotypic analysis of the TGF beta-509 allele in patients with systemic lupus erythematosus and Sjogren's syndrome. Ann. Genet., 47(4), 359-363.

Chen, L.Z., Hochwald, G.M., Huang, C., Dakin, G., Tao, H., Cheng, C. (1998). Gene therapy in allergic encephalomyelitis using myelin basic protein-specific T cells engineered to express latent transforming growth factor-beta1. Proc. Natl. Acad. Sci. USA, 95, 12516-12521.

Cueller, M.L., Espinoza L.R. (1997). Methotrexate use in psoriasis and psoriatic arthritis. Rheum. Dis. Clin. North Amer., 23, 797-809.

Dahler, A.L., Cavanagh, L.L., Saunders, N.A. (2001). Suppression of keratinocyte growth and differentiation by transforming growth factor beta1 involves multiple signaling pathways. Invest. Dermatol., 116(2), 266-274.

De Jong, R., R.AW., van Lier, F.W., Ruscetti, C., Schmitt, P., Debre, M.D. Mossalayi (1993) Differential effect of transforming growth factor- $\beta 1$ on the activation of human naive and memory CD4+ T lymphocytes. Int. Immunol., 6, 631-638. 
Dennler, S., Goumans, M.-J. Dijke, P. (2002) Transforming growth factor $\beta$ signal transduction. J. Leuk. Biol., 71, 731-740.

Elder, J.T., Ellingsworth, L.R., Fisher, G.J., Voorhees, J.J. (1990). Transforming growth factor-beta in psoriasis. Pathogen. Ther. Ann. NY Acad. Sci., 593, 218-230.

Fantini, M.C., Becker, C., Monteleone, G., Pallone, F., Galle, P.R., Neurath, M.F. (2004). Cutting edge, TGF-beta induces a regulatory phenotype in CD4+CD25- T cells through Foxp3 induction and down-regulation of Smad7. J. Immunol., 172(9), 5149-5153.

Gamblicher, T., Breuckmann, F., Boms, S. (2005). Narrowband UVB phototherapy in skin conditions beyond psoriasis. J. Amer. Acad. Dermatol., 53, 1099-1000.

Go, C., Li, P. Wang, X.-J. (1999). Blocking transforming growth factor ß signaling in transgenic epidermis accelerates chemical carcinogenesis. A mechanism associated with increased angiogenesis. Cancer Res., 59, 2861-2868.

Gray, J.D., Hirokawa, M., Horwitz, D.A. (1994). The role of transforming growth factor $B$ in the generation of suppression, an interaction between CD8+ T and NK cells. J. Exp. Med., 180, 1937-1942.

Hammad, A.M., Youssef, H.M., El-Arman, M.M. (2006). Transforming growth factor beta 1 in children with systemic lupus erythematosus, a possible relation with clinical presentation of lupus nephritis. Lupus, 15(9), 608-612.

Han, K.-H., Choi, H.-R., Won, C.-H., Chung, J-H., Cho, K.-H., Eun, H.-C., Kim, K.-H. (2005). Alteration of the TGF- $\beta /$ SMAD pathway in intrinsically and UV-induced skin aging. Mech. Ageing Devel., 126, 560-567.

Hönigsmann, H. (2001). Phototherapy for psoriasis. Clin. Exp. Dermatol., 6, 343-350.

Horwitz, D.A., Gray, D.K. Ohtsuka (1999). Role of NK cells and TGF- $\beta$ in the regulation of T-cell-dependent antibody production in health and autoimmune disease. Microbes Infect., 1(5), 1305-1311.

Jeffes, E.W., McCullough, J.L., Pittelkow, M.R. (1995). Methotrexate therapy of psoriasis, differential sensitivity of proliferating lymphoid andepithelial cells to the cytotoxic and growth-inhibitory effects of methotrexate. J. Invest. Dermatol., 104, 183-188.

Khalil, N. (1999). TGF-beta: From latent to active. Microbes Infect., 1(15), 1255-1263.

Laouar, Y., Sutterwala, F.S., Gorelik, L., Flavell, R.A. (2005). Transforming growth factor- $\beta$ controls $T$ helper type 1 cell development through regulation of natural killer cell interferon- $\gamma$. Nature Immunology, 6, 600-607.

Letterio J.J., Roberts A.B. Regulation of immune responses by TGF- $\beta$ (1998). Апnu. Rev. Immunol., 16, 137-161.

Lu, L.-Y., Cheng, H-H, Sung, P.-K., Yeh, J.-J., Shiue, Y.-L., Chen, A. (2004). Single-nucleotide polymorphisms of transforming growth factor- $\beta 1$ gene in Taiwanese patients with systemic lupus erythematosus. $J$. Microbiol. Immunol. Infect., 370(3), 135-142.

Mahon, B.D., Gordon, S.A., Cruz, J., Cosman, F. Cantorna, M.T. (2003). Cytokine profile in patients with multiple sclerosis following vitamin D supplementation. J. Neuroimmunol., 134, 128-132.

Massague, J. (2000). How cell read TGF- $\beta$ signals. Mol. Cell Biol., 1, $164-177$

Massague, J. (1990). The transforming growth factor- $\beta$ family. Ann. Rev. Cell. Biol., 6, 597-641.

Matsubara, T., Umezawa, Y., Tsuru, S., Motohashi, T., Yabuta, K., Furukawa, S. (1997). Decrease in the concentrations of transforming growth factor-beta 1 in the sera of patients with Kawasaki disease. Scand. J. Rheumatol., 26(4), 314-317.
Mauviel, A. (2009). Transforming growth factor-beta signaling in skin: Stromal to epithelial cross-talk. J. Invest. Dermatol., 129(1), 7-9.

Mieliauskaite, D., Venalis, P., Dumalakiene, I., Venalis, A., Distler, J. (2009). Relationship between serum levels of TGF- $\beta 1$ and clinical parameters in patients with rheumatoid arthritis and Sjogren's syndrome secondary to rheumatoid arthritis. Autoimmunity, 42(4), 356-358.

Ohsugi, I., Imamura, O., Satoh, M., Sugawara, M., Goto, M., Sugimoto, M., Furuichi, Y. (2000). Overexpression of mRNAs of TGF $\beta-1$ and related genes in fibroblasts of Werner syndrome patients. Mech. Ageing Devel. 115(3), 189-198.

Oyama, N., Iwatsuki, K., Satoh, M., Akiba, H., Kaneko, F. (2000). Dermal fibroblasts are one of the therapeutic targets for topical applicationof $1 \alpha, 25$ - dihydroxyvitamin D3, the possible involvement of transforming growth factor- $\beta$ induction. Brit. J. Dermatol., 143, 1140-1148.

Pardali, K., Kurisaki, A., Morén, A., ten Dijke, P., Kardassis, D., Moustakas, A. (2000). Role of Smad proteins and transcription factor Sp1 in p21(Waf1/Cip1) regulation by transforming growth factor-beta. J. Biol. Chem., 275(38), 29244-29256.

Ravitz, M.J. (1997). Cyclin-dependent kinase regulation during G1 phase and cell cycle regulation. Adv. Cancer Res., 71, 165-207.

Rubtsov, Y.P., Rudensky, A.Y. (2007). TGF beta signalling in control of T-cell-mediated self-reactivity. Nat. Rev. Immunol., 7(6), 443-453.

Saltis, J. (1996). TGF-beta: Receptors and cell cycle arrest. Mol. Cell Endocrinol., 116(2), 227-232.

Sellheyer, K., Bickenbach, J.R., Rothnagel, J.A. (1993). Inhibition of skin development by overexpression of transforming growth factor $\beta 1$ in the epidermis of transgenic mice. Proc. Natl. Acad. Sci. USA, 90, 5237-5241.

Shen, L., Smith, J.M., Shen, Z., Eriksson, M., Sentman, C., Wira, C.R. (2007). Inhibition of human neutrophil degranulation by transforming growth factor-beta1. Clin. Exp. Immunol., 149(1), 155-161.

Su, H., Ye, D.Q., Wang, B.L, Fang, X.H., Chen, J., Wang, Q., Li, W.X., Zhang, N. (2008). Transforming growth factor-beta1-induced $\mathrm{CD} 4+\mathrm{CD} 25+$ regulatory $\mathrm{T}$ cells in vitro reverse and prevent a murine lupus-like syndrome of chronic graft-versus-host disease. Brit. J. Dermatol., 158(6), 1197-1209.

Taihao, Q., Tianyuan, H., Sewon, K., Voorhees, J.J., Fisher, G. (2002). U1traviolet irradiation alters transforming growth factor $\beta / \mathrm{Smad}$ pathway in human skin in vivo. J. Investig. Dermatol., 119, 499-506.

Ten Dijke, P., Goumans, M.J., Itoh, F., Itoh, S. (2002). Regulation of cell proliferation by Smad proteins. J. Cell Physiol., 191, 1-16.

Ulloa, L, Doody, J., Massague, J. (1999). Inhibition of transforming growth factor- $\beta /$ SMAD signalling by the interferon- $\gamma /$ STAT pathway. Nature, 397, 710-713

Van Ruissen, F., van Erp, P.E., de Jongh, G.J., Boezeman, J.B., van de Kerkhof, P.C., Schalkwijk, J. (1994). Cell kinetic characterization of growth arrest in cultured human keratinocytes J. Cell Sci., 107(8), 2219-2228.

Wang, X.-J., Greenhalgh, D.A., Bickenbach, J.R., Jiang, A., Bundman, D.S., Krieg, T., Derynck, R., Roop, D.R. (1997). Expression of a dominant-negative type II transforming receptor in the epidermis of transgenic mice blocks TGF- $\beta$-mediated growth inhibition. Proc. Natl. Acad. Sci. USA, 94, 2386-2391.

Weichenthal, M, Schwarz, T. (2005). Phototherapy, how does UV work? Photodermatol Photoimmunol Photomed., 21, 260-266

Widom, R.L. (2000). Regulation of matrix biosynthesis and degradation in systemic sclerosis. Curr. Opin. Rheumatol., 12(6), 534-539. 


\section{TGF- $\beta 1$ KONCENTRĀCIJAS PĀRMAIN̦AS SERUMĀ SLIMNIEKIEM AR SMAGU PSORIĀZES NORISI ĀRSTĒ}

TGF- $\beta 1$ ir universāls un plašas darbības spektra augšanas faktors, kurš nosaka daudzas fizioloğiskas un patoloğiskas norises organismā. Traucējumi TGF-1 augšanas faktora darbībā vai tam pakḷautajos receptoros un signālmolekulās ir saistīti ar daudzām slimībām, labdabīgu un l̦aundabīgu audzēju rašanos, kā arī ar novecošanas procesiem. Ādas apstarošana ar šaura spektra UVB viḷna garumu $311 \mathrm{~nm}$ ir viena no visbiežāk lietojamām ārstēšanas metodēm smagas psoriāzes gadījumos. Mūsu pētījuma mērkis bija izvērtēt atškirīgas iedarbības ārstēšanas metožu ietekmi uz TGF-1 koncentrācijas maiņu serumā slimniekiem ar smagu psoriāzi norisi. TGF-1 koncentrācija asins serumā slimniekiem ar smagu psoriāzi bija statistiski nozīmīgi zemāka salīdzinot ar klīniski veseliem indivīdiem kontrolgrupā. 37 slimniekiem tika nozīmēta $311 \mathrm{~nm}$ šaura spektra UVB fototerapija, 18 slimniekiem - farmakoloğiskā sistēmiskā ārstēšana ar metotreksātu. Pēc divu nedēlu ārstēšanas kursa PASI kritums un TGF-1 seruma koncentrācijas līmeṇa palielinājums tika novērots tiem slimniekiem, kuriem tika nozīmēta šaura spektra UVB fototerapija. TGF-1 deficīts psoriātiskā ādā nosaka tai raksturīgo Th1 un Th17 limfocītu nosacītu imūno reakciju attīstību. In vitro ādas apstarošana ar UVB stimulē TGF-1 izstrādi keratinocītos un fibroblastu šūnās. TGF-1 izstrādes stimulācija ir viens no mehānismiem, kādā veidā, izmantojot UVB starojumu, tiek sasniegts ārstnieciskais efekts slimniekiem ar psoriāzi. 